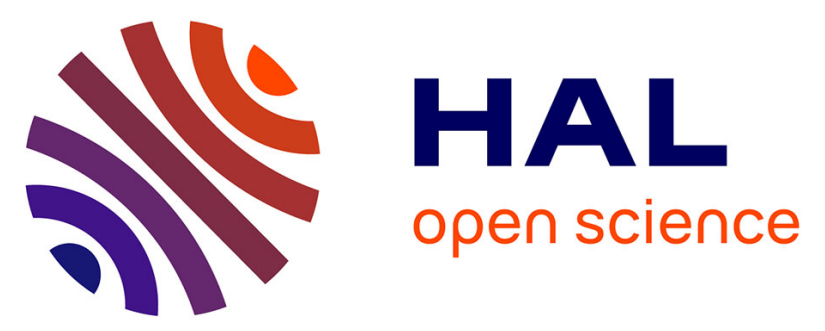

\title{
Influence of coevaporation process on CIGS solar cells with reduced absorber thickness and current enhancement with periodically textured glass substrates
}

L. Grenet, F. Emieux, O. Dellea, A. Gerthoffer, G. Lorin, F. Roux, S. Perraud

\section{- To cite this version:}

L. Grenet, F. Emieux, O. Dellea, A. Gerthoffer, G. Lorin, et al.. Influence of coevaporation process on CIGS solar cells with reduced absorber thickness and current enhancement with periodically textured glass substrates. Thin Solid Films, 2016, 621, pp.188-194. 10.1016/j.tsf.2016.12.011 . cea-02474090

\section{HAL Id: cea-02474090 \\ https://hal-cea.archives-ouvertes.fr/cea-02474090}

Submitted on 11 Feb 2020

HAL is a multi-disciplinary open access archive for the deposit and dissemination of scientific research documents, whether they are published or not. The documents may come from teaching and research institutions in France or abroad, or from public or private research centers.
L'archive ouverte pluridisciplinaire HAL, est destinée au dépôt et à la diffusion de documents scientifiques de niveau recherche, publiés ou non, émanant des établissements d'enseignement et de recherche français ou étrangers, des laboratoires publics ou privés. 


\title{
Influence of coevaporation process on CIGS solar cells with reduced absorber thickness and current enhancement with periodically textured glass substrates
}

\author{
L. Grenet*, F. Emieux, O. Dellea, A. Gerthoffer, G. Lorin, F. Roux, S. Perraud \\ CEA, LITEN, 17 rue des Martyrs, 38054 Grenoble Cedex 9, France
}

\section{A R T I C L E I N F O}

\section{Article history:}

Received 18 July 2016

Received in revised form 10 November 2016

Accepted 7 December 2016

Available online 08 December 2016

\section{Keywords:}

CIGS

Reduced absorber thickness

Light trapping

Coevaporation

1-stage/3-stages

Textured substrates

Periodic

Glass substrate

\begin{abstract}
A B S T R A C T
This study shows the fabrication of CIGS solar cells with various absorber thicknesses synthesized with two different methods: the classical 3-stages coevaporation process and a 1-stage coevaporation process. Structural characteristics and photovoltaics properties as function of absorber thickness are described. 1-stage coevaporation process gives lower efficiencies for CIGS solar cells with nominal absorber thickness $(\sim 2000 \mathrm{~nm})$ but performs similarly or even better when the absorber thickness is decreased down to $600 \mathrm{~nm}$. Periodically textured glass substrates with different feature sizes have been fabricated and used to increase current in 1-stage coevaporated CIGS solar cells. A current improvement up to $4.1 \mathrm{~mA} \cdot \mathrm{cm}^{-2}$ ( $6 \%$ relative) has been obtained leading to an increase in efficiency up to $5 \%$ relative. A maximum increase has been found when texturation size is similar to CIGS absorber thickness.
\end{abstract}

(c) 2016 Elsevier B.V. All rights reserved.

\section{Introduction}

Among thin film technologies, $\mathrm{Cu}$ (In,Ga)Se $\mathrm{Se}_{2}$ (CIGS) solar cells show the best performances with certified power conversion efficiencies above $22.3 \%$ obtained by different groups [1,2]. However, limited indium resources in the earth crust as well as its use in other applications may cap the development of CIGS production capacities to $80 \mathrm{GWp} / \mathrm{year}$ in 2050 [3], far from attaining the terawatt challenge [4].

Decreasing the absorber thickness is the most straightforward solution to reduce indium consumption in CIGS solar cells. However, it implies a reduction of the solar spectrum absorption in the active layer, particularly at long wavelengths, and thus leads to a decreased shortcircuit current (JsC) of the device [5]. Different strategies of light management have been conducted so far to tackle this issue and increase light absorption in the solar cells. One can mention the improvement of back contact reflection with highly reflective gold back contact [6], the introduction of plasmonic Ag nanoparticles as back reflector [7] or the use of dielectric scattering pattern [8].

In order to make these solutions suitable at industrial scale, structures for light trapping must be transferrable at low cost on large surfaces. Decoupling the elaboration of light management structures from solar cells fabrication gives a good opportunity to achieve this goal

\footnotetext{
* Corresponding author.

E-mail address: louis.grenet@cea.fr (L. Grenet).
}

because it does not affect the low cost process flow to fabricate solar cells [9]. Our approach consists in fabricating and using periodically textured glass substrates on which coevaporated CIGS solar cells have been deposited. Techniques used for textured substrates fabrication are compatible with large surfaces $\left(>1 \mathrm{~m}^{2}\right)$ and based on soda-lime glass (SLG) which is traditionally used in CIGS technology.

The first part of this study deals with the comparison of two coevaporation processes to produce CIGS solar cells with reduced absorber thickness while the second part describes the influence of substrate texturation on solar cells photovoltaic properties.

\section{Experimental section}

\subsection{Design of the structure}

The design of the structure used in the second part of this study is depicted in Fig. 1(a). It consists in a 1-mm soda-lime glass (SLG) substrates in which $\mathrm{SiO}_{2}$ spherical particles have been buried. Different diameters of spheres $(0.5 \mu \mathrm{m}, 1.0 \mu \mathrm{m}$ and $2.5 \mu \mathrm{m})$ have been used in order to obtain texturation at different scales (respectively named S-0.5, S-1.0 and S-2.5 in the manuscript). Height of the pattern is about $1 / 3$ of the sphere diameter and period of the texturation can be approximated by the particle diameter. Aspect ratio (defined as pattern height on the period) is thus close to $1 / 3$. A dense thin layer $(50 \mathrm{~nm})$ of $\mathrm{SiO}_{2}$ is deposited before the Mo back electrode in order to prevent Na migration 


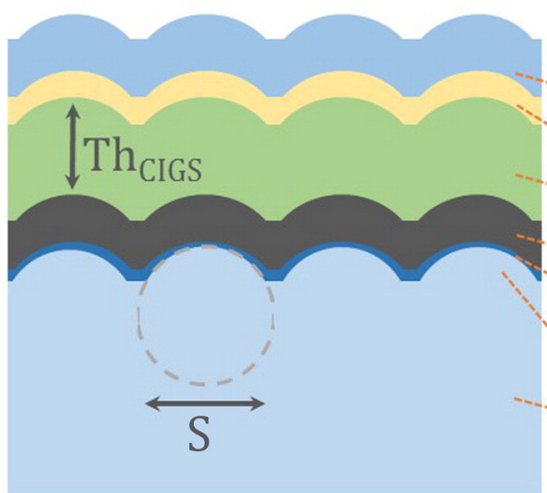

(a)
$\mathrm{ZnO} / \mathrm{ZnO}: \mathrm{Al}$
$\mathrm{CdS}$
$\mathrm{CIGS}$
$\mathrm{Mo}$
$\mathrm{SiO}_{2}$
$\mathrm{SiO}_{2}$ spheres

Glass substrate

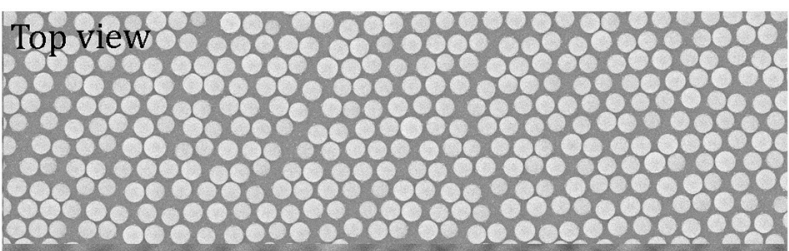

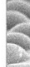

(b)

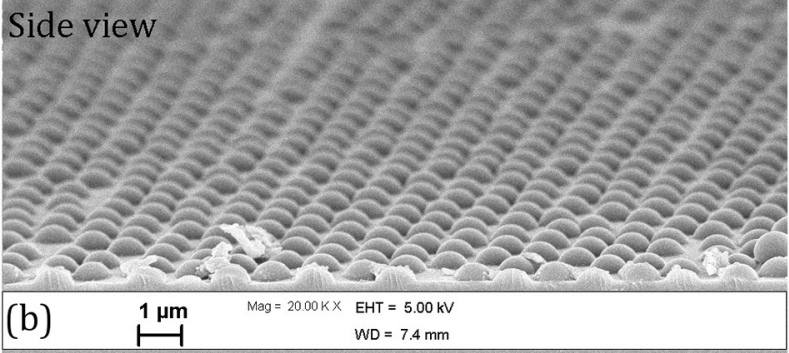

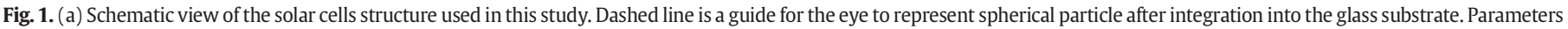

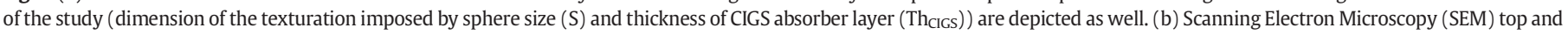
side views of textured glass substrates with $1 \mu \mathrm{m}$ diameter buried spheres (S-1.0).

and other contaminants from the $\mathrm{SLG} / \mathrm{SiO}_{2}$ spheres substrate. First it allows to compare more easily these structures with reference ones (same structures without buried spheres), because the role of $\mathrm{SiO}_{2}$ spheres as diffusion barrier for $\mathrm{Na}$ is unknown. And second, Na diffusion is known to promote formation of $\mathrm{MoSe}_{2}$ at the Mo/CIGS interface [10]. In this study Mo is used as back reflector, thus $\mathrm{MoSe}_{2}$ thickness has to be reduced as much as possible in order to avoid optical losses in this layer. $\mathrm{Na}$ (and K) are however known to improve CIGS solar cells performances and are necessary to achieve high efficiencies: post-deposition treatment [11] can be directly applied to improve this process but has not been used here for the sake of simplification.

A typical Mo/CIGS/CdS/ZnO/ZnO:Al solar cells is deposited on these substrates; all steps of fabrication are described thereafter. Three different thicknesses of the CIGS absorber layer ( $\mathrm{Th}_{\mathrm{CIGS}}$ ) have been used for this study. Exact thicknesses may vary from the targeted values of 2000, 1100 and $600 \mathrm{~nm}$ and have been measured with X-Ray Fluorescence (XRF).

\subsection{Textured substrates fabrication}

The fabrication of the textured glass substrates is based on the deposition of a monolayer of silica spheres on a SLG substrate followed by an annealing step to burry these spheres into the glass. An enhanced LangmuirBlodgett technique oriented to very large planar or non-planar substrates (called Boostream) is used to deposit this monolayer of spheres as described in reference [12]. This method allows homogeneous deposition on large surface $\left(>1 \mathrm{~m}^{2}\right)$ at low cost (CEA estimation for spheres deposition is $3 € \cdot \mathrm{m}^{-2}$ ). The periodicity of the texturation is linked to the shape and dimension of particles as well as the deposition technique. During Langmuir-Blodgett process, spheres automatically arrange in a hexagonal close-packed lattice during transfer from solvent to substrate.

After spheres deposition, a short etching step in $\mathrm{SF}_{6}+\mathrm{CHF}_{3}+\mathrm{O}_{2}$ gaz at 6.6 $\mathrm{Pa}$ is used in order to remove organic residual solvents. Substrates and spheres are then annealed in a lamp furnace at $800{ }^{\circ} \mathrm{C}$ for $30 \mathrm{~s}$ (parameters are varied in the $20^{\circ} \mathrm{C} / 10 \mathrm{~s}$ range depending on the sphere size) under inert $\mathrm{Ar}$ atmosphere to obtain substrates with two-thirds buried spheres.

E-beam evaporation is then used in an Oerlikon Univex chamber to deposit a $50 \mathrm{~nm}$ thick $\mathrm{SiO}_{2}$ layer from $\mathrm{SiO}_{2}$ pellets. This layer is in-situ densified by ion beam bombardment to improve its diffusion barrier property.

\subsection{Solar cells fabrication}

These textured substrates have been used to increase light absorption in CIGS solar cells (Mo/CIGS/CdS/ZnO/ZnO:Al), particularly for devices with thin absorber layers. All deposition steps are compatible with $5 \times 5 \mathrm{~cm}^{2}$ substrates. In order to become insensitive to reproducibility issues, all deposition steps (including $\mathrm{SiO}_{2}$ evaporation and $\mathrm{CdS}$ deposition) have been made simultaneously on $2.5 \times 5 \mathrm{~cm}^{2}$ textured substrates and on $2.5 \times 5 \mathrm{~cm}^{2}$ reference flat substrates which consist in $\mathrm{SiO}_{2}$ coated SLG without texturation. Results based on flat reference substrates are presented in Section 3.1 and a comparison with textured substrates is conducted in Section 3.2.

A $500 \mathrm{~nm}$ Mo back contact is DC-sputtered in an Alliance Concept equipment at room temperature. A low Ar pressure $(0.13 \mathrm{~Pa})$ is used in order to improve reflectivity of the back contact. Description of the coevaporation processes for the CIGS layer is precisely made in the next section. The solar cell is then completed with a $50 \mathrm{~nm}$ thick chemical bath deposited CdS buffer layer and a $50 \mathrm{~nm} / 450 \mathrm{~nm}$ thick $\mathrm{ZnO}$ / $\mathrm{ZnO}$ :Al bilayer RF-sputtered at room temperature in a MRC chamber. $\mathrm{Ni} / \mathrm{Al}$ grids are then deposited to collect current and 9 cells of $0.5 \times 1 \mathrm{~cm}^{2}$ are manually scribed in each sample.

\subsection{CIGS coevaporation}

Two coevaporation routes have been tested for CIGS deposition in this study; both of them have been performed in an Alliance Concept EVA450 deposition chamber. The first one is a classical 3-stages deposition process [13] implying a composition (GGI $=[\mathrm{Ga}] /([\mathrm{In}]+[\mathrm{Ga}]))$ and bandgap gradient in the depth of the absorber layer. This process is described in reference [14]. Another deposition scheme has been tested as well, which consists in coevaporating simultaneously at constant fluxes $\mathrm{Cu}$, In, $\mathrm{Ga}$ and $\mathrm{Se}$ on Mo coated substrates at $550{ }^{\circ} \mathrm{C}$. This process, called 1-stage process, is supposed to give lower efficiencies than the 3stages process but presents other advantages: an easier control of the deposition thickness and a better assessment of the influence of absorber thickness on solar cells properties. Indeed, in the case of 3-stages process, composition gradient are not scalable with the absorber thickness. For a fixed global GGI in the absorber, varying the thickness will modify slopes of the composition gradient and/or GGI at the interfaces and notch (position of minimum bandgap). With 1-stage deposition process, elemental composition as function of depth is much flatter (despite some atomic migration can occur during deposition, see Fig. 2) and influence of absorber thickness on photovoltaic properties become more straightforward. Additionally, is has been argued in reference [9] that 1-stage deposition process could decrease CIGS deposition cost by almost a factor 2 .

For both deposition routes, three absorber thicknesses have been targeted (2000, 1100 and $600 \mathrm{~nm}$; some relatively important shift to targeted thickness have been observed and exact thicknesses are 

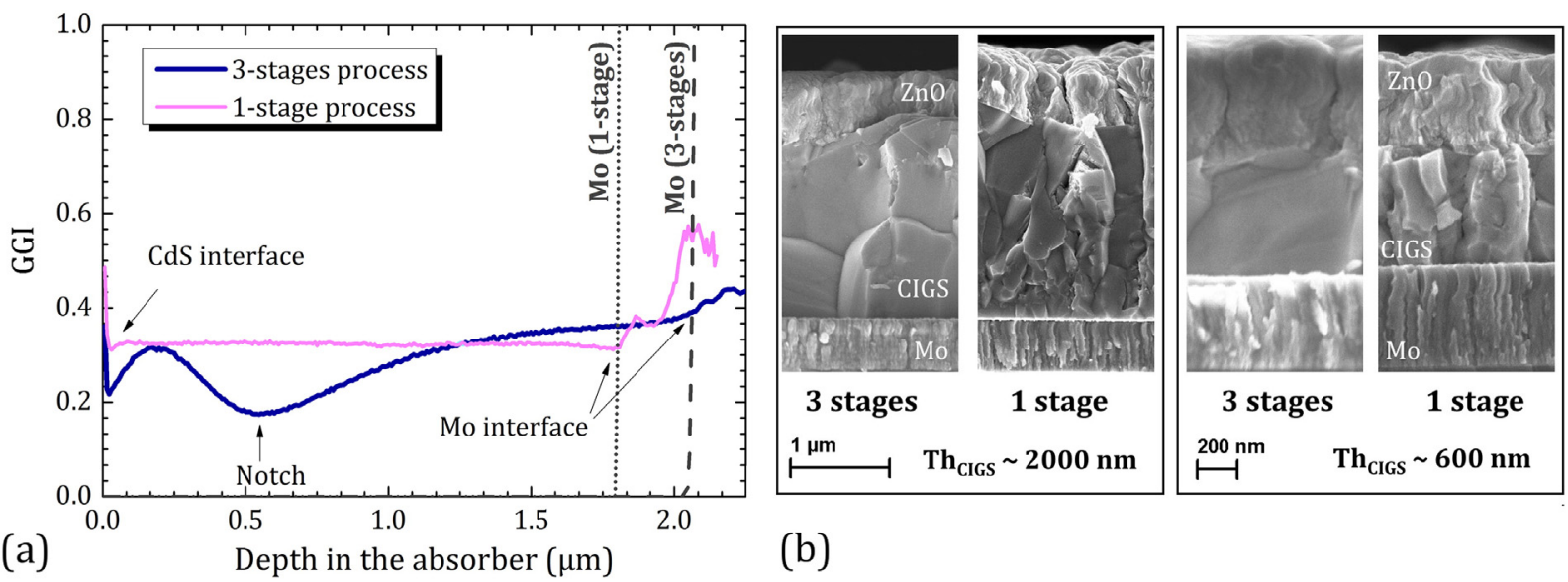

(b)

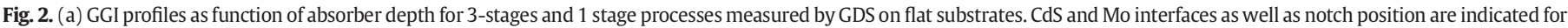
clarity. (b) SEM cross section of CIGS solar cells on reference flat substrates with a $\mathrm{SiO}_{2}$ barrier.

mentioned when necessary), and deposited simultaneously on textured and reference flat substrates. Table 1 summarizes the absorber thicknesses and GGI ratio of the 3 series of samples synthesized for this study measured by X-Ray Fluorescence (XRF). Each series comprises a textured substrate and reference flat substrate for which stoichiometry and thickness are exactly identical.

\subsection{Characterization}

Samples have been characterized by SEM between all steps of the fabrication process in a LEO 1530 Hitachi equipment. Atomic composition of the CIGS absorber layer has been measured by XRF in a Fischerscope X-ray equipment. A Spectra-Nova's CT Series Solar Cell Tester is used to perform current-voltage $(\mathrm{J}-\mathrm{V})$ measurements under simulated AM1.5G spectrum $\left(100 \mathrm{~mW} \cdot \mathrm{cm}^{-2}\right)$. All J-V measurements (light and dark) are performed at $25^{\circ} \mathrm{C}$ in a four-point probe configuration. External quantum efficiency (EQE) measurements are carried out in a ReRa Spequest setup. The in-depth atomic composition of absorber layers was quantified by glow discharge optical emission spectrometry (GDS) using a Horiba GD Profiler 2. Total reflection measurements of the solar cells have been measured in a Perkin Elmer UV/Vis/NIR lambda 950 spectrophotometer with a $150 \mathrm{~mm}$ integration sphere.

\section{Results and discussion}

\subsection{1-stage versus 3-stages deposition processes}

\subsubsection{Structural characterization}

In all processes, a GGI ratio close to 0.30 has been targeted. At nominal thickness ( $2000 \mathrm{~nm}$ ), a GGI ratio of $0.28 \pm 0.02$ (Table 1 ) is obtained corresponding to a CIGS bandgap of $1.15 \pm 0.01 \mathrm{eV}$ [15]. For all samples, a systematic increase of the GGI ratio with decreasing absorber

Table 1

List of thicknesses and GGI ratio for the samples synthesized in this study. Best cells of underlined samples are depicted in Fig. 3(c) and (d).

\begin{tabular}{|c|c|c|c|c|c|c|c|}
\hline & \multirow{2}{*}{$\begin{array}{l}\text { CIGS } \\
\text { thick. } \\
\text { Target } \\
(\mathrm{nm})\end{array}$} & \multicolumn{2}{|c|}{ Series $1(S-0.5)$} & \multicolumn{2}{|c|}{ Series 2 (S-1.0) } & \multicolumn{2}{|c|}{ Series 3 (S-2.5) } \\
\hline & & $\begin{array}{l}\text { Thickness } \\
(\mathrm{nm})\end{array}$ & GGI & $\begin{array}{l}\text { Thickness } \\
(\mathrm{nm})\end{array}$ & GGI & $\begin{array}{l}\text { Thickness } \\
(\mathrm{nm})\end{array}$ & GGI \\
\hline \multirow[t]{3}{*}{ 1-stage } & 600 & 570 & 0.35 & 580 & 0.34 & 470 & \\
\hline & 1100 & 1100 & 0.31 & $\overline{1130}$ & $\overline{0.31}$ & 910 & \\
\hline & 2000 & 1960 & 0.28 & $\overline{2040}$ & $\overline{0.29}$ & 1640 & 0.29 \\
\hline \multirow[t]{3}{*}{ 3-stages } & 600 & 660 & 0.32 & $\overline{640}$ & $\overline{0.30}$ & 540 & 0.32 \\
\hline & 1100 & 1090 & 0.28 & 1070 & 0.28 & $\overline{920}$ & $\overline{0.31}$ \\
\hline & 2000 & 1800 & 0.26 & $\overline{1730}$ & $\overline{0.26}$ & 1720 & 0.30 \\
\hline
\end{tabular}

thickness has been measured. The origin of this variation (up to +0.07 corresponding to a maximum bandgap increase of $38 \mathrm{meV}$ ) is not perfectly clear. It can be either an artefact of XRF measurement since it has only been calibrated at nominal thickness or a real GGI increase.

The main characteristic of 3-stages coevaporated CIGS layers lies into a GGI double gradient in the depth of the absorber [13]. GGI ratio as function of depth for both deposition routes are depicted in Fig. 2(a) for $2000 \mathrm{~nm}$ thick CIGS absorber. The GGI gradient is clearly visible for the 3-stages process while much flatter profile is obtained for the 1-stage process. These measurements have been performed on samples directly synthesized on Mo coated $\mathrm{SLG}$ (no $\mathrm{SiO}_{2}$ diffusion barrier). Thus, amount of $\mathrm{Na}$ is supposed to be higher in the samples for GDS measurements and elemental gradients more pronounced than in the samples fabricated with a $\mathrm{SiO}_{2}$ barrier [16].

SEM cross sections of the different CIGS solar cells deposited on reference substrates with $\mathrm{SiO}_{2}$ diffusion barrier are depicted Fig. 2(b). Samples with nominal thickness ( $2000 \mathrm{~nm})$ are on the left and thin CIGS $(\sim 600 \mathrm{~nm})$ are on the right. In the case of 3-stages coevaporation process, the CIGS layer is made of big grains $(>1 \mu \mathrm{m})$ irrespective of its thickness. This result is consistent with literature: in the absence of $\mathrm{Na}$, big grains are generally observed [16]. On the contrary, grain size is only slightly enhanced without $\mathrm{Na}$ in the case of 1-stage deposition process (comparison with samples deposited on substrates without diffusion barrier is not shown). Again, the grain size is not affected by the thickness of the absorber layer.

\subsubsection{Photovoltaic properties}

The power conversion efficiencies (PCE) of all the cells fabricated on reference substrates with 3-stages and 1-stage coevaporation processes as function of absorber thickness are depicted in Fig. 3. The list of the samples can be found in Table 1: for each deposition route (3-stages or 1-stage), 3 thicknesses ( $\mathrm{Th}_{\mathrm{CIGS}} \sim 600 \mathrm{~nm}, \sim 1100 \mathrm{~nm}$ and $\sim 2000 \mathrm{~nm}$ ) have been used and 3 samples have been fabricated for each thickness. 9 solar cells have been measured on each samples. Mean values presented in the rest of the manuscript are calculated over the 9 cells.

The GGI ratio increase as function of decreasing absorber thickness can induce a CIGS bandgap variation up to $+38 \mathrm{meV}$ for each series of sample and may slightly modify the behavior of solar cells as function of absorber thickness usually reported [5]. The maximum impact on open-circuit voltage $\left(\mathrm{V}_{\mathrm{OC}}\right)$ is $38 \mathrm{mV}$ and on short-circuit current $\left(\mathrm{J}_{\mathrm{SC}}\right)$ is $1.4 \mathrm{~mA} \cdot \mathrm{cm}^{-2}$. However, as far as 1-stage and 3-stages processes are compared for a given thickness, the GGI ratio discrepancy is much lower and the potential effect of such a small variation is carefully discussed thereafter. 

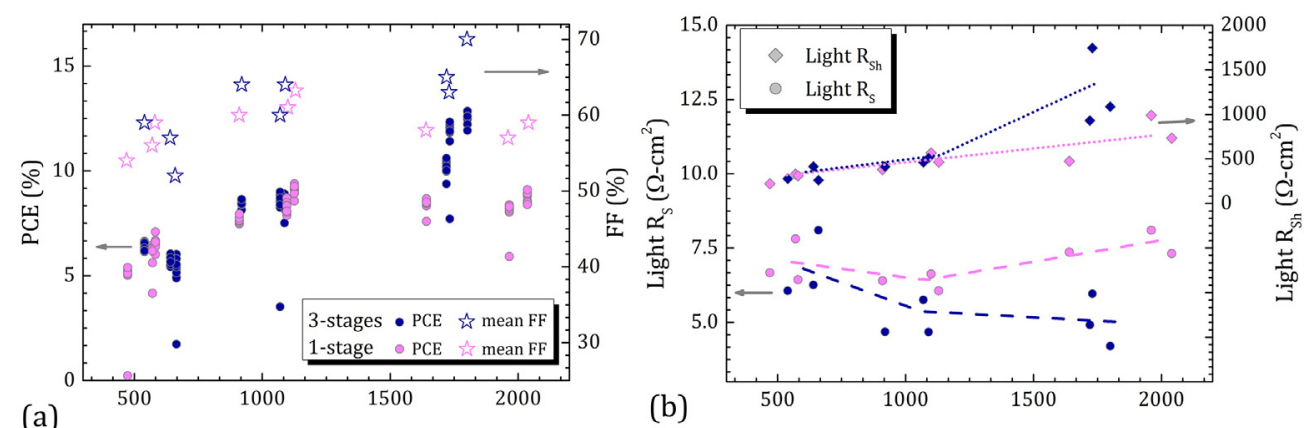

Absorber thickness (nm)
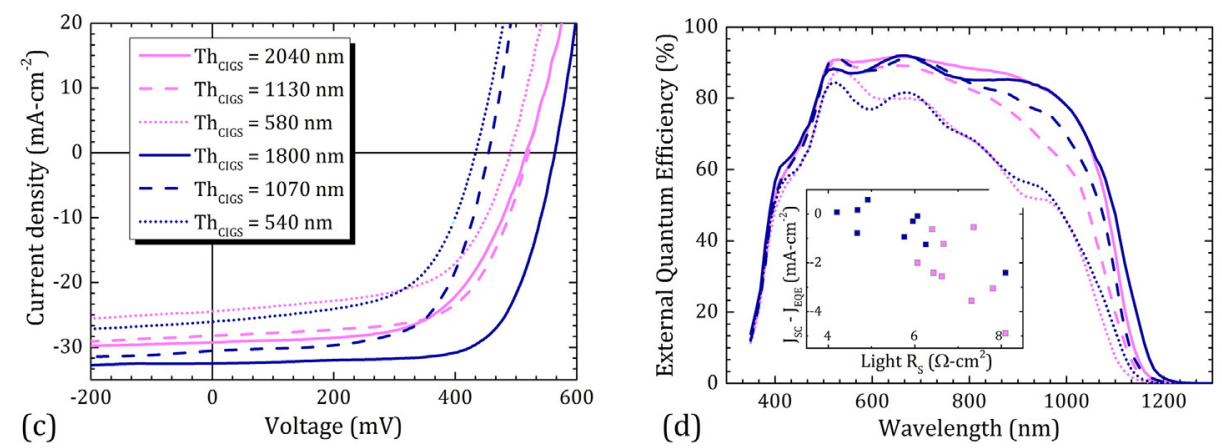

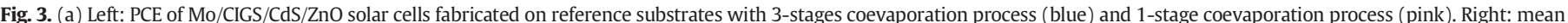

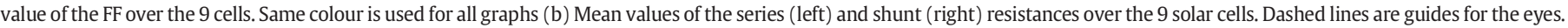

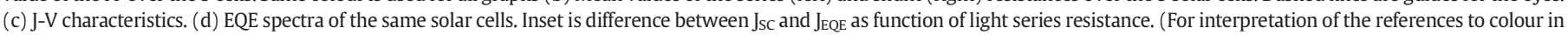
this figure legend, the reader is referred to the web version of this article.)

In the 3-stages case, the PCE of CIGS solar cells continuously decreases with absorber thickness. The best efficiencies (12.9\% due to the absence of $\mathrm{Na}$ ) are obtained for the $1800 \mathrm{~nm}$ thick samples while efficiencies in the range $5 \%-7.5 \%$ are obtained for solar cells with $550 \mathrm{~nm}$ thick absorbers. A different behavior is found for the 1-stage coevaporation process: efficiencies for the thinner samples are comparable or slightly better than in the case of 3-stages process. At intermediate thickness, both processes are still comparable but a saturation of PCE with absorber thickness is obtained at $\sim 1100 \mathrm{~nm}$. As a consequence, PCE for 1-stage process is notably lower for solar cells with nominal thicknesses ( $2000 \mathrm{~nm})$ than for 3-stages process. This behavior is attributed to a lower fill factor (FF) for the 1-stage process than for the 3-stages process (Fig. 3(a)). The lower FF at nominal thickness in the case of 1-stage coevaporation process is caused by a higher series resistance $R_{S}$ (Fig. 3(b)). Mean value of the $R_{S}$ over the 9 cells measured under illumination is similar for both processes at low thicknesses but significantly higher values are measured for the 1-stage process for solar cells with thicker absorber layers. At nominal thickness, lower shunt resistance $\left(R_{S h}\right)$ are equally measured for the 1-stage process contributing to the lower FF.

$\mathrm{J}-\mathrm{V}$ characteristics and EQE measurements of selected cells ( 1 cell per deposition process and thickness - underlined in Table 1) are depicted in Fig. 3(c) and (d) respectively. J-V curves show that 1-stage process suffer principally at nominal thickness from lower FF $(-10 \%$ absolute) than 3-stages process. A lower $\mathrm{J}_{\mathrm{SC}}\left(-3.2 \mathrm{~mA} \cdot \mathrm{cm}^{-2}\right)$ is equally observed and cannot be totally explained by the difference in the GGI ratio between the 2 samples (maximum contribution of $-0.6 \mathrm{~mA} \cdot \mathrm{cm}^{-2}$ ). However, the lack in $\mathrm{JSC}_{\mathrm{SC}}$ is not translated in the EQE measurements: for $\mathrm{Th}_{\mathrm{CIGS}} \sim 2000 \mathrm{~nm}$ samples, integration of $\mathrm{EQE}$ gives $\mathrm{J}_{\mathrm{EQE}}=32.2 \mathrm{~mA} \cdot \mathrm{cm}^{-2}$ for 3 -stages process $\left(\mathrm{J}_{\mathrm{SC}}=\right.$ $32.5 \mathrm{~mA} \cdot \mathrm{cm}^{-2}$ ) and $\mathrm{J}_{\mathrm{EQE}}=32.3 \mathrm{~mA} \cdot \mathrm{cm}^{-2}$ for 1 -stage process $\left(\mathrm{J}_{\mathrm{SC}}=29.2 \mathrm{~mA} \cdot \mathrm{cm}^{-2}\right)$. The notable difference between JSC and JEQE in the case of 1-stage process is explained by the high $R_{S}$. Indeed, a clear correlation is found between $\mathrm{J}_{\mathrm{SC}}-\mathrm{J}_{\mathrm{EQE}}$ and light $\mathrm{R}_{\mathrm{S}}$ for all deposition processes as depicted in the inset of Fig. 3(d). Jsc is clearly limited by series resistance while this effect is not sensitive for EQE because of the lower amount of current generated during this measurement. It provides a further evidence that $R_{S}$ is playing an important role in limiting PCE for 1-stage process at nominal thickness.

The lower JsC and FF of the 1-stage process is offset by a higher $\mathrm{V}_{\mathrm{OC}}$ for the intermediate and low thickness samples. This higher $\mathrm{V}_{\mathrm{OC}}$ $(\sim 60 \mathrm{mV})$ cannot be totally attributed to a variation in bandgap due to composition changes: GGI ratio given by XRF for the considered samples are roughly similar (Table 1 ) and can only explain a $15 \mathrm{mV}$ difference. This is confirmed by EQE measurements. Fitting of dark J-V curves reveals that dark saturation current is slightly decreased with small increase in ideality factor for 1-stage process. Both reasons explain a higher $\mathrm{V}_{\mathrm{OC}}$ but further analysis to explain this differences have not been carried out.

These results confirm that the 3-stages process gives better efficiency for CIGS solar cells with nominal absorber thickness (Th $\sim 2000 \mathrm{~nm}$ ) principally because of a better FF due to lower series resistance. However, as far as ultrathin absorber are targeted (Th $\mathrm{CIGS}_{\mathrm{G}}$ $<500 \mathrm{~nm}$ ), 1-stage deposition process are very promising since they exhibit comparable or better efficiencies at reduced deposition cost [9].

\subsection{1-stage coevaporated CIGS on textured substrates}

All CIGS layers with different conditions (1-stage/3-stages for various $\mathrm{Th}_{\mathrm{CIGS}}$ ) presented in the previous section on reference flat substrates have been deposited simultaneously on textured substrates. Textured substrates with sphere diameters of $0.5 \mu \mathrm{m}$ (S-0.5), $1.0 \mu \mathrm{m}$ (S-1.0) and $2.5 \mu \mathrm{m}(\mathrm{S}-2.5)$ have been used in Series 1, Series 2 and Series 3 respectively.

However, the low $R_{S h}$ obtained for thin samples synthesized with the 3-stages process is even more decreased by the use of textured substrates. Thus, a majority of these cells are short-circuited and results are not useable. As a consequence, and since 1-stage coevaporation process is more promising for CIGS solar cells with reduced absorber thickness, 
Table 2

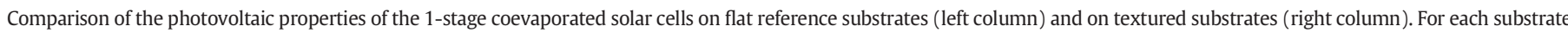

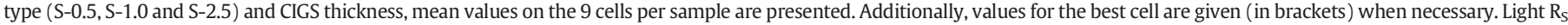
and $R_{S h}$ are extracted from J-V curves under AM1.5 spectrum.

\begin{tabular}{|c|c|c|c|c|c|c|c|c|c|c|c|c|c|c|}
\hline \multirow[b]{2}{*}{ Substrate } & \multirow{2}{*}{$\begin{array}{l}\mathrm{Th}_{\mathrm{CIGS}} \\
(\mathrm{nm})\end{array}$} & \multirow[b]{2}{*}{ Name } & \multicolumn{2}{|l|}{$\begin{array}{l}\text { PCE } \\
(\%)\end{array}$} & \multicolumn{2}{|l|}{$\begin{array}{l}\mathrm{FF} \\
(\%)\end{array}$} & \multicolumn{2}{|l|}{$\begin{array}{l}\text { VOC } \\
(\mathrm{mV})\end{array}$} & \multicolumn{2}{|l|}{$\begin{array}{l}\text { JSC } \\
\left(\mathrm{mA} \cdot \mathrm{cm}^{-2}\right)\end{array}$} & \multicolumn{2}{|l|}{$\begin{array}{l}\text { Light RS } \\
\left(\Omega \cdot \mathrm{cm}^{2}\right)\end{array}$} & \multicolumn{2}{|l|}{$\begin{array}{l}\text { Light RSh } \\
\left(\Omega \cdot \mathrm{cm}^{2}\right)\end{array}$} \\
\hline & & & Ref. & Text. & Ref. & Text. & Ref. & Text. & Ref. & Text. & Ref. & Text. & Ref. & Text. \\
\hline S-0.5 & 570 & $\mathrm{Th}_{\mathrm{CIGS}} 570 / \mathrm{S}-0.5$ & $6.0(6.5)$ & $4.4(6.6)$ & $56(58)$ & $44(56)$ & $483(493)$ & $392(506)$ & $22.2(22.6)$ & $22.1(23.2)$ & $7.8(6.9)$ & $10.0(9.2)$ & $329(297)$ & $203(585)$ \\
\hline \multirow[t]{3}{*}{ S-1.0 } & 580 & $\mathrm{Th}_{\mathrm{CIGS}} 580 / \mathrm{S}-1.0$ & $6.6(7.1)$ & $2.7(6.0)$ & $59(59)$ & $33(53)$ & $488(490)$ & $360(512)$ & $22.9(24.5)$ & $19.4(22.4)$ & $6.4(4.9)$ & $19.5(8.5)$ & $310(293)$ & $70(201)$ \\
\hline & 1130 & $\mathrm{Th}_{\mathrm{CIGS}} 1130 / \mathrm{S}-1.0$ & 9.1 & 5.1 & 63 & 37 & 520 & 492 & 27.6 & 27.8 & 6.1 & 20.9 & 465 & 189 \\
\hline & 2040 & $\mathrm{Th}_{\mathrm{CIGS}} 2040 / \mathrm{S}-1.0$ & 8.7 & 5.2 & 59 & 37 & 513 & 504 & 28.7 & 27.4 & 7.3 & 22.3 & 734 & 281 \\
\hline \multirow[t]{3}{*}{ S-2.5 } & 470 & Th $_{\text {CIGS }} 470 / \mathrm{S}-2.5$ & 4.6 & 0.9 & 54 & 26 & 401 & 188 & 20.3 & 18.8 & 6.7 & 17.4 & 222 & 21 \\
\hline & 910 & $\mathrm{Th}_{\mathrm{CIGS}} 910 / \mathrm{S}-2.5$ & 7.7 & 4.9 & 60 & 39 & 487 & 457 & 26.2 & 26.9 & 6.4 & 11.6 & 381 & 74 \\
\hline & 1640 & $\mathrm{Th}_{\mathrm{CIGS}} 1640 / \mathrm{S}-2.5$ & 8.4 & 8.7 & 58 & 53 & 490 & 514 & 29.4 & 31.8 & 7.4 & 7.8 & 473 & 231 \\
\hline
\end{tabular}

only results concerning 1-stage coevaporated CIGS layers on textured substrates are presented thereafter.

For each sample, 9 solar cells have been manually scribed. Their mean photovoltaic properties are summarized in Table 2 for both textured and flat reference substrates. For S-0.5 and S-1.0 at Th $600 \mathrm{~nm}$, photovoltaic properties of best cells have been added since only a few cells are properly working on these samples. Adhesion of CIGS layer with $\mathrm{Th}_{\mathrm{CIGS}}=1100 \mathrm{~nm}$ and $\mathrm{Th}_{\mathrm{CIGS}}=1960 \mathrm{~nm}$ on S-0.5 texturation is not good enough and delamination occurred (visual and SEM observations). These samples have thus been removed from the Table 2 and discarded from further analysis.

The effect of substrate texturation on $\mathrm{J}_{S C}$ is shown in Fig. 4(a). As suggested in reference [17], current improvement is expected to occur when the period of texturation (roughly approximate by sphere diameter in our case) is equal or slightly higher than the absorber thickness. This behavior is qualitatively observed in our case: S-2.5 texturation leads to $\mathrm{J}_{\mathrm{SC}}$ increase for thick and intermediate CIGS (mean JSC gain obtained on the 9 cells: $2.5 \mathrm{~mA} \cdot \mathrm{cm}^{-2}$ and $0.6 \mathrm{~mA} \cdot \mathrm{cm}^{-2}$ for Th $\mathrm{CIGS}_{1640 / \mathrm{S}-}$ 2.5 and $\mathrm{Th}_{\mathrm{CIGS}} 910 / \mathrm{S}-2.5$ respectively; a maximum $\mathrm{J}_{\mathrm{SC}}$ gain of $4.1 \mathrm{~mA} \cdot \mathrm{cm}^{-2}$ is obtained in the first case). S-1.0 texturation outperforms reference flat substrate only for intermediate CIGS thickness (mean Jsc gain of $0.5 \mathrm{~mA} \cdot \mathrm{cm}^{-2}$ for $\mathrm{Th}_{\mathrm{CIGS}} 1130 / \mathrm{S}-1.0$ ) and the only texturation improving current for the thinnest CIGS absorber is the smallest one S- 0.5 (mean Jsc gain of $1.0 \mathrm{~mA} \cdot \mathrm{cm}^{-2}$ for $\mathrm{Th}_{\mathrm{CIGS}} 570 / \mathrm{S}$ $0.5)$. For all other cases, texturation scale is either too large $\left(\right.$ Th $_{\text {CIGS }} 470 / \mathrm{S}-2.5$, Th $_{\text {CIGS }} 580 / \mathrm{S}-1.0$ ) or too small (Th CIGS $\left.2040 / \mathrm{S}-1.0\right)$ to enhance current in solar cells.

EQE measurements for samples with increased $\mathrm{J}_{S C}$ due to texturation are shown in Fig. 5(a). All curves show the same behavior: the maximum value of EQE at short wavelength is not modified by texturation while EQE is notably increased at long wavelengths were light absorption in CIGS is insufficient. This improvement, only in the red part of the spectrum, as well as an unincreased maximum EQE are the hallmark of a current gain due to light trapping into the absorber rather than antireflection due to increased roughness [18]. This is further confirmed by total reflection $\left(R_{T}\right)$ measurements of the same solar cells depicted in Fig. 5(b). Up to $1000 \mathrm{~nm}$, only a small decrease in $\mathrm{R}_{\mathrm{T}}$ with the use of textured substrates is observed: the mean reflection reduction in the $350 \mathrm{~nm}-1000 \mathrm{~nm}$ range is $<1.0 \%$ absolute for S- 0.5 and S-1.0 (top graph) and between $1.5 \%$ and $1.75 \%$ absolute for S-2.5 (middle graph). At longer wavelength, antireflection effect starts to play a role (mean $R_{T}$ decrease in the $1000 \mathrm{~nm}-1250 \mathrm{~nm}$ is comprised between $3 \%$ and $10 \%$ absolute). Effective light trapping in the absorber layer can be assessed with the Internal Quantum Efficiency (IQE) defined as: $\mathrm{IQE}=\mathrm{EQE} /\left(1-\mathrm{R}_{\mathrm{T}}\right)$. The IQE gain (defined as $\left(\mathrm{IQE}_{\mathrm{Text}}-\mathrm{IQE}_{\mathrm{Ref} .}\right) / \mathrm{IQE}_{\mathrm{Ref}}$. where $\mathrm{IQE}_{\mathrm{Text}}$ and $\mathrm{IQE}_{\text {Ref. }}$ refer to IQE on textured substrates and flat reference substrates respectively) obtained with the use of textured substrates is depicted in Fig. 5(b) (bottom). At short wavelengths, flat reference substrates perform similarly or even slightly better than textured substrates because of lower light absorption in $\mathrm{CdS}$ and $\mathrm{ZnO}$. At longer wavelengths, a significant gain is obtained with the use of textured substrates, which confirms that light trapping into the absorber layer occurs. By comparing IQE and EQE gains, we calculated that $40 \%$ to $80 \%$ of the measured current enhancement is due to light coupling into the CIGS layer.

Additional optical studies are needed to better understand the effect of texturation for light management at solar cell level. Particularly, the effect of texturation size on optical losses in supporting layers (Mo, $\mathrm{ZnO}, \mathrm{CdS}$ ) [19] has to be quantified. A better understanding of light incoupling into absorber and comparison of diffraction versus diffusion (obtained with non-ordered spheres) will be developed in a future article.

These promising results in term of current enhancement are not perfectly reflected into PCE improvement (Fig. 4(b)): in only two cases, texturation leads to increased efficiency: namely $\mathrm{Th}_{\mathrm{CIGS}} 570 / \mathrm{S}-0.5$ and $\mathrm{Th}_{\mathrm{CIGS}} 1640 / \mathrm{S}-2.5$ for which a relative increase in PCE of $2 \%$ and $5 \%$
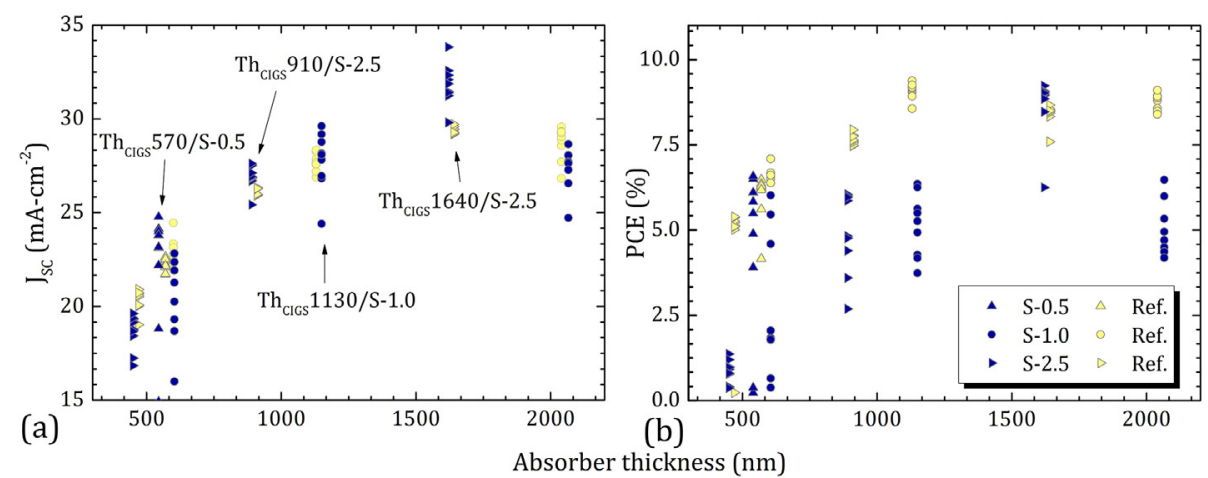

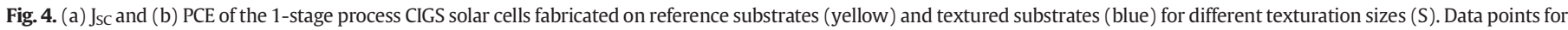

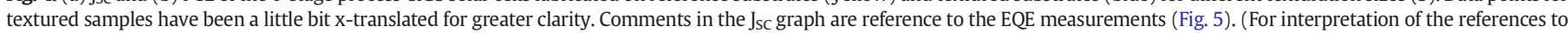
colour in this figure legend, the reader is referred to the web version of this article.) 

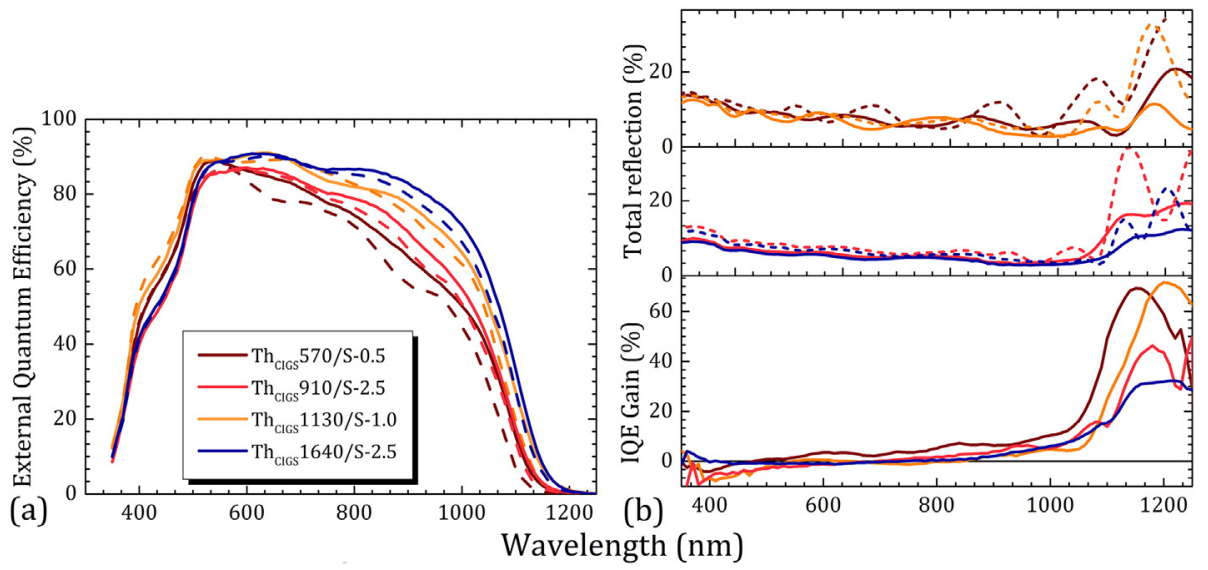

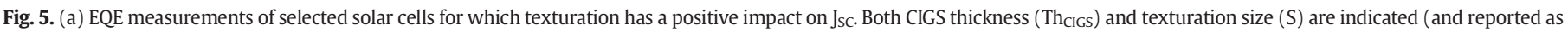

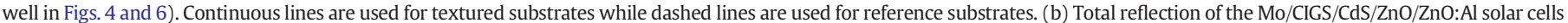
deposited on reference flat substrates (dashed lines) and textured substrates (continuous line). IQE gain (= $\left.\left(\mathrm{IQE}_{\mathrm{text}}-\mathrm{IQE}_{\mathrm{ref}}\right) / \mathrm{IQE}_{\mathrm{ref}}\right)$ of the same cells achieved with texturation.

relative are obtained. In the other cases ( $\mathrm{Th}_{\mathrm{CIGS}} 1130 / \mathrm{S}-1.0$ and $\left.\mathrm{Th}_{\mathrm{CIGS}} 910 / \mathrm{S}-2.5\right)$, the decrease of the FF dominates the current gain.

Indeed, solar cells on textured substrates suffer from a systematically lower FF than the solar cells on flat reference substrates (Table 2). This decrease is attributed to a higher $R_{S}$ as well as a smaller $R_{S h}$. When the shunt resistance is too strongly impacted by the substrate texturation (Light $\mathrm{R}_{\mathrm{Sh}}<70 \Omega \cdot \mathrm{cm}^{2}$ ), degradation of the $\mathrm{V}_{\mathrm{OC}}$ is equally observed. On the contrary, when light $R_{S h}$ have similar values for flat and textured substrates, $\mathrm{V}_{\mathrm{OC}}$ in the latter case can be very slightly improved due to a small increase in the diode ideality factor in the dark (measurement not shown).

The higher $R_{S}$ in the case of textured substrates is attributed to an increase of the sheet resistance of the Mo and $\mathrm{ZnO}$ :Al supporting layers. Sheet resistance of the back electrode on flat reference substrate is $0.33 \Omega . \square^{-1}$ while values between $0.70 \Omega . \square^{-1}$ and $1.60 \Omega . \square^{-1}$ have been measured for S-0.5, S-1.0 and S-2.5. Texturation also implies an increased roughness for $\mathrm{ZnO}$ :Al deposition which leads to a higher sheet resistance in this layer [20].

Origin of $R_{S h}$ decrease has been tentatively explained with SEM cross-sections depicted in Fig. 6. First, it is obvious that the growth of Mo back contact is strongly affected by the size of texturation. For S0.5 , the $\mathrm{SiO}_{2}$ spheres lead to the formation of almost disjointed Mo pillar while a very conformal Mo deposition is obtained for S-2.5. Intermediate S-1.0 texturation reveals rather good conformity of Mo layer on $\mathrm{SiO}_{2}$ spheres with however smoothed texturation. As a consequence, CIGS deposition is very conformal for S-2.5 and the texturation provided by the glass substrate is translated to $\mathrm{ZnO}$ layer on top of the solar cell. It is not the case for $\mathrm{S}-0.5$ texturation because grain size is not much smaller than texturation size and aspect ratio of the glass features is softened by the Mo growth.

Thus, for samples with important texturation transferred at the Mo/ CIGS interface (i.e. large scale compared to CIGS grain size, namely S-1.0 and S-2.5), $\mathrm{R}_{\mathrm{Sh}}$ strongly decrease when the absorber thickness is too low (i.e. comparable to grain size) because CIGS cannot accommodate the texuration of the substrate. This result is particularly highlighted in the $\mathrm{Th}_{\mathrm{CIGS}} 910 / \mathrm{S}-2.5$ case for which $\mathrm{R}_{\mathrm{Sh}}$ is below $100 \Omega \cdot \mathrm{cm}^{2}$ on textured substrates. SEM pictures made on 3-stages coevaporated CIGS solar cells on textured substrates (not shown) confirm this assumption: as the size of grains obtained on reference flat substrates is not affected by texturation it is not possible to have a perfectly conformal CIGS layer with grain size similar or bigger than texturation features. Thus $R_{S h}$ decrease for 3-stages process is even more pronounced on textured substrates than for 1-stage process.
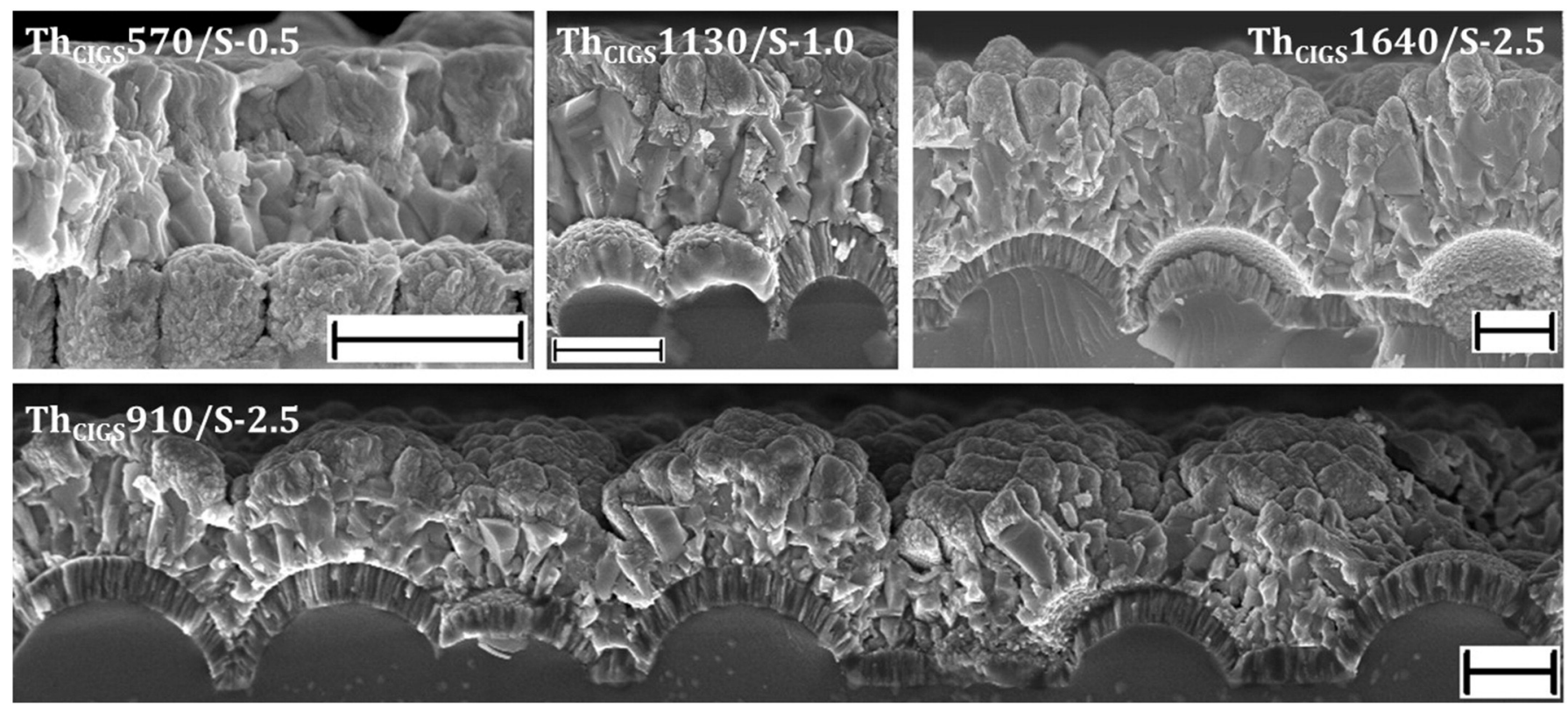

Fig. 6. SEM cross section of the samples characterized in Fig. 5. All scale bars are $1 \mu \mathrm{m}$. 
This technological problem of grain size versus texturation size can be partially solved by decreasing grain size with incorporating more $\mathrm{Na}$ into the absorber layer. Thus, post-deposition treatments are expected to improve the process at $\mathrm{V}_{\mathrm{OC}}$ level (decrease of recombination [11]) as well as $\mathrm{FF}$ (increase in $\mathrm{R}_{\mathrm{Sh}}$ due to smaller grains).

From these SEM pictures, it can be mentioned as well that the disjoint pillar growth for S- 0.5 texturation can explain the poor adherence of CIGS layers on these textured substrates.

\section{Conclusion}

In this study, we explored two routes for fabricating CIGS solar cells with decreased absorber layer thicknesses. Additionally to the classical 3-stages coevaporation route, we demonstrated that the 1-stage coevaporation method can be chosen as far as solar cells with reduced absorber thicknesses are targeted. The lower efficiency at nominal thickness due to higher $\mathrm{R}_{\mathrm{S}}$ is not observed for thinner samples and comparable or better performances are obtained for submicronic CIGS solar cells.

CIGS solar cells with thin absorber thickness suffer from low Jsc due to insufficient light absorption. We have used periodically textured glass substrates to improve light trapping into CIGS absorber layers and we have demonstrated that it allows to obtain current (up to $4.1 \mathrm{~mA} \cdot \mathrm{cm}^{-2}$, >6\% relative) and efficiency (up to $5 \%$ relative) increase in our 1-stage coevaporated solar cells.

The process described in this study can be easily improved by incorporation of alkali post-deposition treatment in order to achieve higher efficiency. Further developments have to be carried out to notably increase reflectivity of the back contact in order to obtain more pronounced current gain. Finally, the proof of concept of using textured glass substrates for CIGS solar cells with reduced absorber thickness has been demonstrated.

\section{Acknowledgement}

This work was supported by the European Union's Seventh Framework Program FP7/2007-2013 (grant agreement, 261901: AGATHA).

\section{References}

[1] https://www.zsw-bw.de/fileadmin/user_upload/PDFs/Pressemitteilungen/2016/ pr09-2016-ZSW-WorldRecordCIGS.pdf.

[2] http://www.solar-frontier.com/eng/news/2015/C051171.html.
[3] C. Candelise, M. Winskel, R. Gross, Implications for CdTe and CIGS technologies production costs of indium and tellurium scarcity, Prog. Photovolt. Res. Appl. 20 (6) (2012) 816-831.

[4] R.E. Smalley, Future global energy prosperity: the terawatt challenge, MRS Bull. 30 (06) (2005) 412-417.

[5] O. Lundberg, M. Bodegård, J. Malmström, L. Stolt, Influence of the $\mathrm{Cu}(\mathrm{In}, \mathrm{Ga}) \mathrm{Se}_{2}$ thickness and Ga grading on solar cell performance, Prog. Photovolt. Res. Appl. 11 (2) (2003) 77-88.

[6] Z.J. Li-Kao, N. Naghavi, F. Erfurth, J.F. Guillemoles, I. Gérard, A. Etcheberry, J.L. Pelouard, S. Collin, G. Voorwinden, D. Lincot, Towards ultrathin copper indium gallium diselenide solar cells: proof of concept study by chemical etching and gold back contact engineering, Prog. Photovolt. Res. Appl. 20 (5) (2012) 582-587.

[7] G. Yin, A. Steigert, P. Andrae, M. Goebel, M. Latzel, P. Manley, I. Lauermann, S Christiansen, M. Schmid, Integration of plasmonic Ag nanoparticles as a back reflector in ultra-thin $\mathrm{Cu}(\mathrm{In}, \mathrm{Ga}) \mathrm{Se}_{2}$ solar cells, Appl. Surf. Sci. 355 (2015) 800-804.

[8] C. van Lare, G. Yin, A. Polman, M. Schmid, Light coupling and trapping in ultrathin $\mathrm{Cu}(\mathrm{In}, \mathrm{Ga}) \mathrm{Se}_{2}$ solar cells using dielectric scattering patterns, ACS Nano 9 (10) (2015) 9603-9613.

[9] K.A. Horowitz, R. Fu, M. Woodhouse, An analysis of glass-glass CIGS manufacturing costs, Sol. Energy Mater. Sol. Cells 154 (2016) 1-10.

[10] T. Wada, N. Kohara, S. Nishiwaki, T. Negami, Characterization of the Cu(In,Ga) $\mathrm{Se}_{2}$ Mo interface in CIGS solar cells, Thin Solid Films 387 (1) (2001) 118-122.

[11] A. Chirilă, P. Reinhard, F. Pianezzi, P. Bloesch, A.R. Uhl, C. Fella, L. Kranz, D. Keller, C. Gretener, H. Hagendorfer, D. Jaeger, R. Erni, S. Nishiwaki, S. Buecheler, A.N. Tiwari, Potassium-induced surface modification of $\mathrm{Cu}(\mathrm{In}, \mathrm{Ga}) \mathrm{Se}_{2}$ thin films for high-efficiency solar cells, Nat. Mater. 12 (12) (2013) 1107-1111.

[12] O. Delléa, O. Shavdina, P. Fugier, P. Coronel, E. Ollier, S.F. Désage, Control methods in microspheres precision assembly for colloidal lithography, International Precision Assembly Seminar, Springer, Berlin Heidelberg 2014, pp. 107-117.

[13] M.A. Contreras, J. Tuttle, A. Gabor, A. Tennant, K. Ramanathan, S. Asher, A. Franz, J Keane, L. Wang, J. Scofield, R. Noufi, High efficiency $\mathrm{Cu}(\mathrm{In}, \mathrm{Ga}) \mathrm{Se}_{2}$-based solar cells: processing of novel absorber structures, Conference Record of the 24th IEEE Photovoltaic Specialists Conference, 1, 1994, pp. 68-75.

[14] C. Roger, S. Noël, O. Sicardy, P. Faucherand, L. Grenet, N. Karst, H. Fournier, F. Roux, F. Ducroquet, A. Brioude, S. Perraud, Characteristics of molybdenum bilayer back contacts for $\mathrm{Cu}(\mathrm{In}, \mathrm{Ga}) \mathrm{Se}_{2}$ solar cells on Ti foils, Thin Solid Films 548 (2013) 608-616.

[15] P.D. Paulson, R.W. Birkmire, W.N. Shafarman, Optical characterization of CuIn ${ }_{x} \mathrm{Ga}_{\mathrm{x}} \mathrm{Se}_{2}$ alloy thin films by spectroscopic ellipsometry, J. Appl. Phys. 94 (2003) $879-888$.

[16] D. Rudmann, G. Bilger, M. Kaelin, F.J. Haug, H. Zogg, A.N. Tiwari, Effects of NaF coevaporation on structural properties of $\mathrm{Cu}(\mathrm{In}, \mathrm{Ga}) \mathrm{Se}_{2}$ thin films, Thin Solid Films 431 (2003) 37-40.

[17] H. Sai, K. Saito, N. Hozuki, M. Kondo, Relationship between the cell thickness and the optimum period of textured back reflectors in thin-film microcrystalline silicon solar cells, Appl. Phys. Lett. 102 (5) (2013).

[18] H. Sai, M. Kondo, Light trapping effect of patterned back surface reflectors in substrate-type single and tandem junction thin-film silicon solar cells, Sol. Energy Mater. Sol. Cells 95 (1) (2011) 131-133.

[19] C. Onwudinanti, R. Vismara, O. Isabella, L. Grenet, F. Emieux, M. Zeman, Advanced light management based on periodic textures for $\mathrm{Cu}(\mathrm{In}, \mathrm{Ga}) \mathrm{Se}_{2}$ thin-film solar cells, Opt. Express 24 (6) (2016) A693-A707.

[20] M. Lluscà, A. Antony, J. Bertomeu, Growth and properties of $\mathrm{ZnO}$ : Al on textured glass for thin film solar cells, Int. J. Photoenergy (2014) (406495). 